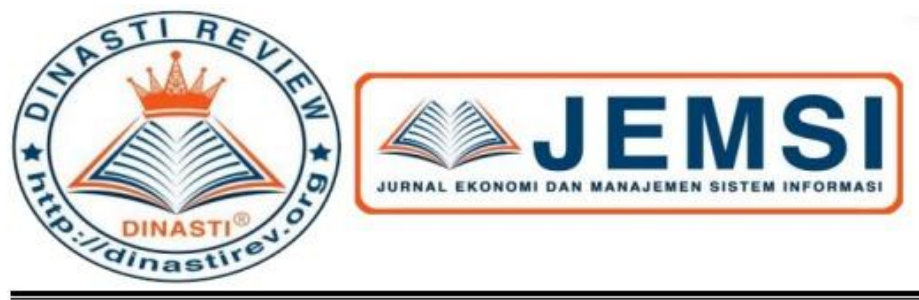

+62 878-9658-6407

087896586407 ()

https://dinastirev.org/JEMSI (-)

editor@dinastirev.org (G.

\title{
PENYELARASAN TEKNOLOGI INFORMASIDENGAN STRATEGI BISNIS
}

\author{
Nurdien Ashshidiqy ${ }^{1}$, Hapzi Ali ${ }^{2}$ \\ 1) Universitas Mercu Buana, Jakarta \\ ${ }^{2)}$ Universitas Mercu Buana, Jakarta
}

\begin{tabular}{|c|c|}
\hline $\begin{array}{l}\text { ARTICLE INFORMATION } \\
\text { Received: } 24 \text { Agustus } 2019 \\
\text { Revised: } 31 \text { Agustus } 2019 \\
\text { Issued: } 5 \text { September } 2019\end{array}$ & $\begin{array}{l}\text { Abstrak: Sukses dalam persaingan dalam sebuah } \\
\text { bisnis terkait dengan pengembangan kompetensi inti, } \\
\text { keselarasan strategi dan perencanaan strategis jangka } \\
\text { panjang agar dapat mempertahankan keunggulan } \\
\text { kompetitif dari sebuah bisnis. Sebuah perusahaan } \\
\text { membutuhkan keselarasan antara strategi Teknologi } \\
\text { Informasi dan Strategi Bisnis. Perencanaan Strategi } \\
\text { Teknologi Informasi merupakan langkah pertama } \\
\text { antara proses dari sebuah sistem informasi perusahaan } \\
\text { dan merupakan pedoman dari system informasi } \\
\text { perusahaan serta dasar pelaksanaan. Tulisan ini } \\
\text { bertujuan untuk membahas bagaimana membuat } \\
\text { perencanaan strategis Teknologi Informasi yang tepat. } \\
\text { Setelah membahas Model Keselarasan Strategis dan } \\
\text { hubungan antara Teknologi Informasi strategi dan } \\
\text { strategi bisnis dapat nerencanakan rencana strategis } \\
\text { yang didasarkan pada strategi bisnis, yang terdiri } \\
\text { Teknologi Informasi penilaian dan analisis, } \\
\text { perencanaan dan desain Teknologi Informasi serta } \\
\text { implementasi dan desain Teknologi Informasi. } \\
\text { Kemudian, memberikan contoh untuk menggambarkan } \\
\text { bagaimana membuat perencanaan strategis Teknologi } \\
\text { Informasi dengan menggunakan model tersebut. } \\
\text { Kata Kunci: Strategi IT, Strategi Bisnis, Perencanaan } \\
\text { Strategi IT, Model Strategi IT }\end{array}$ \\
\hline
\end{tabular}

\section{PENDAHULUAN}

Penyelarasan antar bisnis strategi dengan teknologi informasi (IT) merupakan permasalahan yang kompleks dan bersifat multidimensi. Seringkali keputusan untuk melakukan pengembangan dibidang teknologi informasi hanya didasarkan pada kemampuan sebuah perangkat lunak yang canggih tanpa melihat lebih jauh apakah perangkat lunat tersebut telah sesuai dengan kebutuhan organisasi dalam jangka panjang. Tentu penggunaan aplikasi yang canggih dapat memberikan keuntungan dalam bersaing (competitive advantage) bagi perusahaan. Tetapi keuntungan yang diberikan dengan cara ini tidak akan dapat berlangsung lama. Apabila ternyata ada perangkat lunak baru dengan kemampuan yang lebih 
canggih, maka keuntungan yang dimiliki tentu akan ikut hilang bersamaan dengan munculnya perangkat lunak yang baru tersebut.

Dalam lingkungan konvensional, hubungan antara strategi kompetitif perusahaan dan manfaat penggunaan Teknologi Informasi dikembangkan melalui beberapa lapisan yaitu dari perencanaan, Analisa, dan perancangan. Dapat dipahami bila pada lingkungan seperti ini Teknologi Informasi memiliki pengaruh yang kecil terhadap strategi kompetitif perusahaan. Sejalan dengan semakin luasnya pemanfaatan Teknologi Informasi di lingkungan bisnis, semakin terlihat tidak ada lagi pemisahan antara Teknologi Informasi dan Strategi kompetitif perusahaan, karena semua strategi kompetitif harus memiliki Teknologi Informasi sama halnya dengan memiliki marketing, produsen dan keuangan. Strategi Teknologi Informasi membantu manager untuk mendefinisikan batasan pembuatan keputusan untuk tindakan berikutnya, tapi menghentikan dengan singkat dalam menentukan tindakan untuk dirinya sendiri. Hal ini merupakan perbedaan mendasar antara Strategi Teknologi Informasi dan perencanaan Teknologi Informasi.

Strategi Teknologi Informasi merupakan kumpulan prioritas yang menguasai pembuatan keputusan bagi user dan proses data profesional. Hal itu merupakan bentuk aturan framework untuk kegunaan Teknologi Informasi dalam perusahaan, dan menjelaskan bagaimana seorang eksekutif senior pada perusahaan akan berhubungan pada infrastruktur Teknologi Informasi. Perencanaan Teknologi Informasi memfokuskan pada pelaksanaan dari Strategi Teknologi Informasi. Oleh karena itu tujuan dari penelitian ini menyelaraskan rencana strategi Teknologi Informasi yang didasarkan pada strategi manajemen Teknologi Informasi dan strategi bisnis agar dapat meningkatkan daya saing perusahaan dan pada akhirnya membantu perusahaan mencapai strategi bisnis mereka.

Perkembangan dari era ekonomi pengetahuan membuat Teknologi Informasi menjadi kompetitif dan merupakan sebuah cara yang efektif untuk dapat membantu perusahaan bertahan di kalangan masyarakat modern dan mendapatkan efek pembangunan yang lebih besar. Dalam menghadapi ekonomi globalisasi ini, setiap perusahaan mulai merasa khawatir tentang sistem informasi untuk memperkuat daya saing mereka. Namun di beberapa negara, tingkat keberhasilan sebuah sistem informasi perusahaan tidak tinggi. Dari beberapa kasus perusahaan yang konstruksi sistem informasinya gagal, dapat dilihat bahwa sebagian besar perusahaan tidak membuat perencanaan Strategi Teknologi Informasi yang sistematis dan ilmiah pada tahap awal, sehingga perencanaan Strategi Teknologi Informasi menjadi tidak jelas dan penilaian menjadi tidak pasti dalam kriteria seleksi teknis. Sebaliknya, perusahaanperusahaan yang sukses memiliki keseluruhan baik perencanaan Strategi Teknologi Informasi maupun Strategi Bisnis. Pembangunan tahap demi tahap sebuah sistem informasi dan memperbaiki sistem tersebut secara bertahap perlu dilakukan. Perencanaan Strategi Teknologi Informasi dan Strategi Bisnis untuk tahap demi tahap pelaksanaan adalah pilihan terbaik untuk pembagunan sistem informasi perusahaan. Secara keseluruhan perencanaan Strategi Teknologi Informasi dan Strategi Bisnis harus didasarkan pada pengembangan Strategi Bisnis di tingkat strategi dan kemudian mengembangkan perencanaan tindakan yang layak.

\section{METODE PENELITIAN}

Pada penelitian dilakukan tahap-tahapan sebagai berikut:

1) Persiapan

2) Studi pustaka

3) Menyelaraskan Perencanaan Strategi Teknologi Informasi dan Strategi Bisnis 
a. Fase penyelarasan perencanaan strategi Teknologi Informasi dengan strategi bisnis yang telah dijalankan perusahaan.

- Formulasi Strategi Teknologi Informasi

- Perencanaan Teknologi Informasi

- Peningkatan Kualitas dan Program Inovasi Teknologi Informasi

b. Fase Pengembangan Organisasi

- Strategi Teknologi Informasi

- Perencanaan Teknologi Informasi dan TQM/IS

Strategi Teknologi Informasi membantu manager untuk mendefinisikan batasan pembuatan keputusan untuk tindakan berikutnya, tapi menghentikan dengan singkat dalam menentukan tindakan untuk dirinya sendiri. Hal ini merupakan perbedaan mendasar antara Strategi Teknologi Informasi dan perencanaan Teknologi Informasi. Strategi Teknologi Informasi merupakan kumpulan prioritas yang menguasai pembuatan keputusan bagi user dan proses data profesional. Hal itu merupakan bentuk aturan framework untuk kegunaan IT dalam perusahaan, dan menjelaskan bagaimana seorang eksekutif senior pada perusahaan akan berhubungan pada infrastruktur Teknologi Informasi. Perencanaan Teknologi Informasi pada hal lain, memfokuskan pada pelaksanaan dari Strategi Teknologi Informasi.

Hal-hal yang termasuk dalam Teknologi Informasi adalah:

1) Aplikasi proses transaksi

2) Proses informasi dan aplikasi pelaporan

3) Sistem pendukung keputusan

4) Sistem pendukung eksekutif

5) Produktivitas profesional dan alat berkelompok

6) Sistem berbasis ilmu pengetahuan dan kecerdasan tiruan

7) Proses automatisasi dan robotic

8) Desain dan automatisasi pabrik; dan

9) Teknologi yang berada dalam komputer (seperti "smartcard" atau ATMs)

Pendekatan Teknologi Informasi/Penyelarasan Strategi tidak hanya dirancang untuk menutup kemungkinan strategi Teknologi Informasi; berarti untuk memfasilitasi perundingan tentang kepercayaan manajemen dan pelatihan industri dengan:

a. Mengajukan pertanyaan yang relevan dan membantu struktur individu yang mereka fikirkan dan percaya.

b. Menjawab pertanyaan yang diajukan, berdasarkan pada pengalaman perusahaan.

c. Membangun konsensus disekitar prinsip yang terbaik dalam memetakan kebutuhan dari lingkungan kompetitif; dan

d. Membangun sebuah laporan review program untuk memastikan implementasi memantau pengembangan strategi, dan untuk mengubah prinsip sebagai pergantian kondisi.

Hal penting dalam proses Teknologi Informasi /Penyelarasan Strategi:

a) Posisi dan lingkup aktifitas Teknologi Informasi;

b) Kebutuhan resources dan batasan; dan

Organisasi dan Manajemen Teknologi Informasi.

\section{HASIL DAN PEMBAHASAN}

\section{Rencana Strategi Teknologi Informasi dan Keuntungannya}

Perencanaan strategis Teknologi Informasi bergantung pada hasil penilaian Teknologi Informasi, itu akan mengembangkan atau menyesuaikan arahan sistem informasi dari perusahaan dan mengupayakan untuk skala yang paling cocok dan biaya yang paling pantas untuk mendapatkan informasi pekerjaan yang harus dilakukan. Pertama, sesuai dengan 
kebutuhan strategis perusahaan, kita harus memiliki visi dan misi yang jelas perusahaan dari teknologi informasi dan menentukan arah pembangunan sistem informasi perusahaan dan fungsi bisnis teknologi informasi dalam mencapai strategi bisnis proses. Kedua, kita perlu menyusun sebuah program untuk mengarahkan sistem kerja perusahaan. Karena ini merupakan konstitusi yang harus diikuti oleh departemen teknologi informasi ketika mengimplementasikan tugasnya. Pada saat yang sama, itu merupakan jaminan untuk menyelesaikan misi informasi secara efektif. Ketiga, tujuan Sistem informasi perusahaan harus didefinisikan karena mereka adalah tugas yang perlu dilakukan selama tahun-tahun mendatang untuk menjamin tercapainya visi dan misi.

Adapun keuntungan dari rencana strategi Teknologi Informasi:

a) Perencanaan strategis Teknologi Informasi dapat mempromosikan konsistensi antara strategi bisnis dan item konstruksi sistem informasi perusahaan seperti kecepatan, arah, serta kemampuan memperbaiki perusahaan untuk mengendalikan Teknologi Informasi dan peningkatan daya saing perusahaan.

b) Perusahaan dapat memutuskan apa yang harus difokuskan dan kinerja masa depan pengembangan usaha. Hal ini juga dapat menghindari fenomena bahwa produsen Teknologi Informasi tidak bertanggung jawab mengganggu perusahaan untuk meluncurkan informasi skala besar denganteknologi dalam mengejar keuntungan mereka sendiri.

c) Perencanaan strategis Teknologi Informasi mempromosikan pemimpin eksekutif untuk mencapai konsensus pada ideologi, kunci mengarahkan bidang aplikasi dan faktor penentu keberhasilan sistem informasi.

d) Perencanaan strategis Teknologi Informasi dapat membantu staf Teknologi Informasi dan staf aplikasi untuk mengetahui apa yang harus mereka miliki di masa depan, seperti pengetahuan, keterampilan, dan kriteria memilih teknologi.

e) Perencanaan strategis Teknologi Informasi dapat membantu perusahaan untuk meningkatkan kemampuan meningkatkan pendapatan investasi Teknologi Informasi dan mengurangi risiko secara efektif.

\section{Rencana Strategi Teknologi Informasi Berdasarkan Bisnis Strategi}

Teknologi informasi mengubah cara perusahaan mengatur proses bisnis mereka, berkomunikasi dengan calon pelanggan dan memberikan layanan mereka. Faktor kunci keberhasilan untuk perusahaan yang sukses adalah keselarasan yang efektif dan efisien dalam mendukung strategi dan proses bisnis Teknologi Informasi (Lihat Gambar 1). Kebutuhan dan keinginan menyelaraskan kebutuhan bisnis dan kemampuan Teknologi Informasi. Dalam survei tahunan Manajemen Informasi, keselarasan Teknologi Informasi dan bisnis merupakan peringkat pertama yang mendapat perhatian dari enam tahun terakhir ini. Keselarasan antara bisnis kebutuhan dan kemampuan Teknologi Informasi masih merupakan area yang menonjol dari keprihatinan. Jadi, dapat dengan mudah dilihat bahwa membuat strategi Teknologi Informasi adalah bukan berarti murni masalah teknis, tetapi manajemen yang berorientasi dengan masalah. Strategi Teknologi Informasi harus fokus pada informasi dari pada teknologi karena sistem informasi itu sendiri tidak menciptakan informasi, informasi yang hanya dapat datang dari kegiatan tidak peduli melalui saluran apa. Tetapi kita perlu tahu sumber dan arah arus informasi ini adalah perencanaan strategis dasar Teknologi Informasi. Untuk itu kita harus mempunyai pemahaman mendalam tentang strategi bisnis dan struktur organisasi dari suatu perusahaan.

\section{Penyelarasan Strategi Teknologi Informasi}


Sebagaimana yang dinyatakan oleh Venkatraman, Henderson dan Oldach, Strategic Alignment Model (SAM) menjelaskan bisnis dan keselarasan Teknologi Informasi sepanjang dua dimensi (Gambar 1). Dimensi strategic fit membedakan antara fokus eksternal, diarahkan terhadap lingkungan bisnis, dan fokus internal serta struktur administrasi. Selanjutnya yaitu dimensi integrasi fungsional memisahkan bisnis dan Teknologi Informasi. Secara keseluruhan, model mendefinisikan empat domain yang telah diselaraskan untuk mencapai keselarasan. Masing-masing domain memiliki komponen penyusunnya: ruang lingkup, kompetensi, pemerintahan, infrastruktur, proses dan keterampilan. Henderson dan Venkatraman membayar perhatian luas dengan pendekatan yang berbeda untuk mencapai keselarasan ini. Mengikuti pendekatan yang lebih holistik ini, kita mendefinisikan penyelarasan bisnis dan Teknologi Informasi sebagai sejauh mana aplikasi Teknologi Informasi, infrastruktur dan organisasi, mengaktifkan dan mendukung strategi bisnis dan proses, serta proses untuk menyadari hal ini.

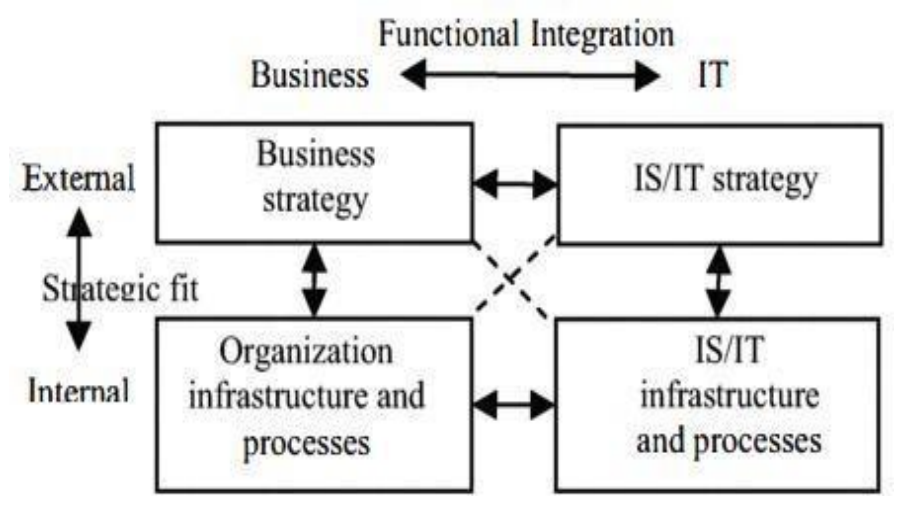

Gambar 1. Strategic Alignment Model (SAM)

\section{Model Rencana Strategi Teknologi Informasi Berdasarkan Strategi Bisnis}

Strategi Teknologi Informasi terkait erat dengan strategi bisnis. Teknologi Informasi akan menjadi pendorong untuk pengembangan usaha. Jika tidak, Teknologi Informasi akan menjadi tulang untuk suatu perusahaan. Dalam rangka untuk membuat kompetensi strategi Teknologi Informasi dengan strategi bisnis, orang perlu memahami hubungan antara Teknologi Informasi dan strategi dan tahu apa strategi bisnis dan akhirnya bekerja di luar strategi Teknologi Informasi yang sesuai dengan strategi bisnis. Gambar 2 adalah proses perencanaan strategi Teknologi Informasi berdasarkan strategi bisnis.

Menilai dan menganalisis Teknologi Informasi untuk memahami apakah perusahaan memberikan layanan yang berkualitas kepada para penggunanya, perusahaan harus melakukan penilaian kemampuannya. Penilaian ini harus mencakup lima bidang utama: mendapatkan bisnis strategis perencanaan, fungsi bisnis perusahaan itu dan proses dasar; menganalisis bisnis, membedakan teknologi Teknologi Informasi dan gambaran besar tujuan pembangunan Teknologi Informasi; menganalisis kondisi sistem informasi saat ini; memeriksa apakah bisnis tersebut cocok dengan Teknologi Informasi; menilai infrastruktur Teknologi Informasi saat ini. 


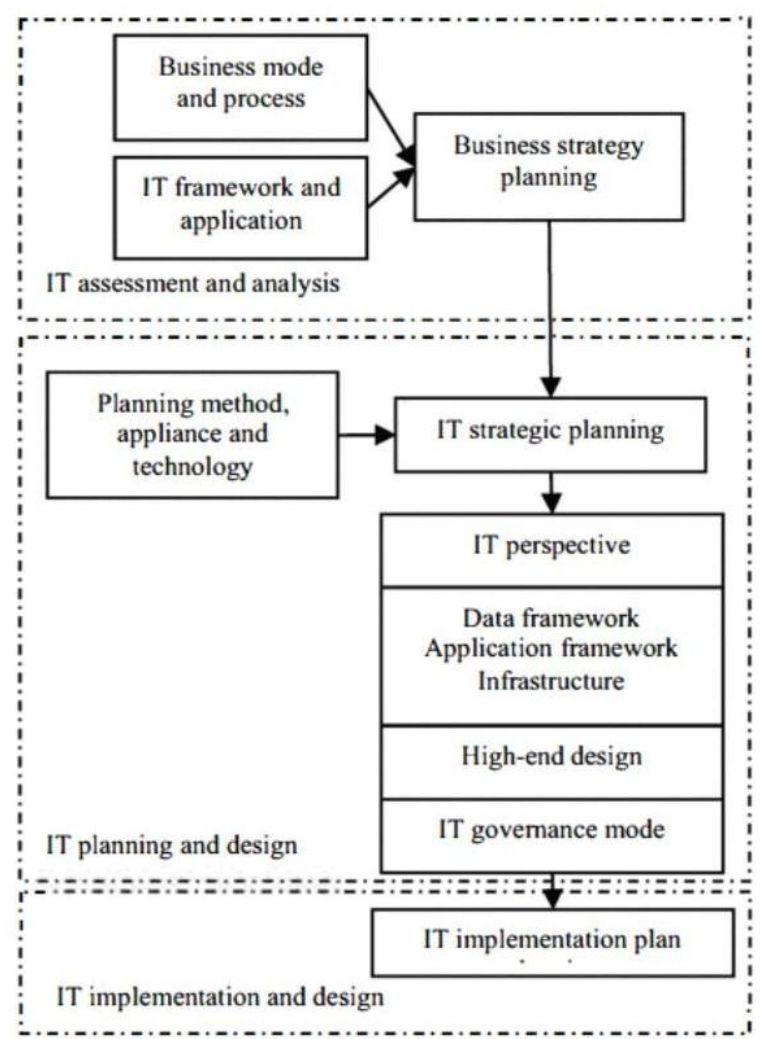

\section{Gambar 2 Proses perencanaan strategi Teknologi Informasi berdasarkan strategi bisnis}

Perencanaan dan desain Teknologi Informasi. Strategi Teknologi Informasi, pembangunan kerangka Teknologi Informasi masa depan dan modus pengelolaan Teknologi Informasi di masa depan selesai dalam langkah ini. Strategi Teknologi Informasi meliputi: Teknologi Informasi perspektif yang menentukan efek dari Teknologi Informasi di perusahaan; kerangka perusahaan yang merupakan standar untuk merancang kerangka aplikasi, data kerangka kerja dan infrastruktur; desain high-end yang berisi standarisasi, operasi inti sistem, e-bisnis, platform database, strategi pusat data dan strategi pusat pemulihan bencana. Prinsip-prinsip utama adalah fasilitasi, standardisasi, modularisasi dan integrasi.

Implementasi dan desain Teknologi Informasi. Tugas pada langkah ini menemukan faktor penentu keberhasilan, mendefinisikan dan menyortir proyek-proyek tertentu, mengkonfirmasikan waktu dan tugas untuk setiap langkah, memperkirakan anggaran dan peramalan hasil.

Mengembangkan perencanaan strategis dengan cara ini dapat membantu memastikan keselarasan kebutuhan bisnis dan aktivitas Teknologi Informasi. Memiliki rencana tersebut dapat menguntungkan perusahaan dalam beberapa cara. Pertama, rencana tersebut menyediakan arahan yang jelas untuk barang-barang penting. Proyek Teknologi Informasi harus jatuh ke dalam item penting dalam rencana, sehingga menghilangkan proyek yang tidak perlu. Kedua, semua orang akan harus "mendayung" ke arah yang sama. Ketika orang-orang baris di arah yang berlawanan, sedikit atau tidak ada kemajuan dalam bergerak perahu ke depan. Ketiga, tim keuangan bisnis akan memiliki tampilan tingkat tinggi mendanai kebutuhan Teknologi Informasi. Akhirnya, strategis perencanaan adalah cara yang baik untuk memotivasi departemen pengguna untuk membeli ke dalam strategi karena mereka erat terlibat dalam proses pengembangan strategi. 


\section{Pembahasan}

\section{Keuntungan selarasnya IT dengan strategi bisnis}

Penggunaan IT harus memperhatikan kepentingan - kepentingan perusahaan secara luas, seperti memenuhi kebutuhan para stake holder, mencari strategi - strategi baru, menyelaraskan sumber daya IT dengan kebutuhan bisnis, atau mengurangi duplikasi yang terjadi pada sistem, proses ataupun data. Penggunaan IT yang berjalan sesuia dengan strategi bisnis yang ditetapkan antara lain:

1) Efisiensi operasional : keselarasan IT dan bisnis strategi akan memberikan keuntungan berupa pengurangan biaya operasi. Komponen system architecture dan technology architecture merupakan komponen - komponen yang dikembangan guna mencapai efisiensi operasional. Komponen ini menyediakan arsitektur IT secara komprehensif dan menunjukkan bagaimana berbagai sumber daya IT bekerja.

2) Efektifitas proses. Keselarasan IT dan bisnis strategi dapat meningkatkan efektifitas proses. Peningkatan proses memerlukan analisis yang baik pada komponen business architecture dan system architecture yang diperlukan untuk melakukan kegiatan bisnis. Dalam mengembangkan EA dilakukan pemetaan proses yang sudah ada, dan dibentuk skenario untuk melakukan peningkatan proses dan bagaimana sistem perangkat lunak dapat membantu proses tersebut.

3) Penciptaan kesempatan. Terbuka kesempatan - kesempatan baru untuk mendapatkan keuntungan dan kesempatan untuk menjalankan strategi baru.

4) Efisiensi otamatisasi. Hubungan antar arah strategis dari perusahaan dan technology architecture memungkinkan perencanaan infrastruktur untuk mendukung rencana masa depan perusahaan. Akan diambil keputusan - keputusan proyek otomatisasi untuk perusahaan secara keseluruhan.

Proses Teknologi Informasi /penyelarasan strategi dimulai dengan kebutuhan penafsiran strategi Teknologi Informasi dan diagnosa masalah yang mengizinkan eksekutif untuk menyediakan pengertian pada kebutuhan kritis, objektifitas, dan prioritas yang mereka hadapi. Jika memungkinkan, interview dapat dipimpin oleh anggota dari tiap grup berikut: senior management, senior functional professionals, staf analis, dan IS management.

Daftar pertanyaan untuk interview dan kuisioner dapat dirancang pada konsultasi dengan satu atau dua senior eksekutif untuk memastikan bahwa semua area yang penting dari aktifitas tercakupi. Cakupannya harus memiliki hal-hal berikut:

a) Penjelasan singkat dari objektifitas, ruang lingkup, dan rencana dari proyek dan sebuah deskripsi dari metodologi;

b) Objektifitas/prioritas/keputusan dari bisnis utama;

c) Ruang untuk mengembangkan dukungan Teknologi Informasi (aplikasi dan/atau layanan);

d) Interface dengan grup dan organisasi lain (internal dan eksternal);

e) Proyeksi dari kebutuhan masa depan;

f) Masalah kebijakan seperti kekuasaan, daya hitung dan persetujuan langsung; dan

g) Feedback pada interview.

Setelah mengidentifikasi strategi bisnis organisasi, selanjutnya dapat diadakan workshop untuk eksekutif guna menjelaskan implikasi strategi kompetitif perusahaan terhadap eksplorasi Teknologi Informasi. Workshop ini dapat difasilitasi dengan agen netral atau mungkin konsultan, dan diawali dengan pemaparan strategi bisnis yang berhubungan dengan interview dan kuisioner, dokumen strategi yang ada, dan beberapa interview eksternal.

Strategi Teknologi Informasi yang didapat dari fase I terdiri dari beberapa elemen:

1) Penempatan dan target kesempatan;

a. Asumsi kritis 

b. Aturan kompetitif Teknologi Informasi
c. Sasaran dan ukuran dari nilai Teknologi Informasi
d. Aplikasi strategi dan perkiraan resiko

2) Kompetensi dasar;
a. Kompetensi pengembangan sistem baru
b. Kompetensi sistem operasi
c. Sumber kompetensi.

3) Manajemen dan Organisasi

a. Perencanaan dan tanggung jawab control

b. Tanggung jawab ekseskusi dan operasi

c. Hubungan bisnis/IS

d. Resiko kooperatif

Perencanaan Teknologi Informasi adalah sebuah definisi dari masa depan yang memperbolehkan teknologi menjadi alat yang kompetitif, memberikan permasalahan dan kesempatan menghadapi bisnis.

Pengembangan sebuah perencanaan Teknologi Informasi dimulai dengan perkiraan pada lingkungan Teknologi Informasi yang ada untuk mendukung kegiatan bisnis. Hal ini termasuk perkiraan tentang aplikasi yang digunakan untuk bisnis, database dan struktur yang mendukung bisnis, dan teknologi yang digunakan. Perencanaan Teknologi Informasi menjelaskan mekanisne dimana Sistem Informasi dan bisnis dapat meningkatkan hubungan yang terpercaya, dengan pertimbangan sebagai berikut:

a) Struktur dan penempatan

b) Aturan dan tanggung jawab

c) Performa dan sistem pelaporan; dan

d) Pengguna dan pendidikan Isistem Informasi dan training.

Strategi Teknologi Informasi harus dihasilkan dari proses yang menyediakan platfomr dimana dibangunnya kegunaan teknologi informasi yang kompetitif, dan secara alami dapat diperluas program kualitas Teknologi Informasi yang akan mengganti keadaan yang ada.

\section{Hambatan dalam penyelarasan}

Penyelarasan antar strategi bisnis dan IT merupakan tantangan yang berat bagi perusahaan. Diperlukan usaha yang keras untuk melakukan perubahan budaya perusahaan untuk dapat menerima teknologi baru dan melihat IT sebagai enabler dan bagian yang tak terpisahkan dari organisasi untuk mencapai keberhasilan dalam jangka panjang. Hal ini juga berkaitan dengan kepercayaan para manajer dan pegawai terhadap IT serta laporan - laporan yang diterbitkan menggunakan IT.

Hambatan lainnya berasal dari struktur manajemen perusahaan. Struktur perusahaan dapat menghambat terjadinya komunikasi antar bagian, terutama untuk perusahaan yang terdisentralisasi. Perusahaan seperti ini memiliki unit - unit yang lokasinya berbeda, sehingga komunikasi antar unit - unit ini menjadi tantangan tersendiri. Perusahaan perusahaan yang beroperasi di daerah yang bebeda juga mengalami kesulitan untuk menggunakan strategi dan prosedur yang sama. Hal ini disebabkan karena kompleksitas jangkauan dan pasar yang dituju. Strategi bisnis yang berbeda pada unit - unit yang berbeda ini bisa menyebabkan proses penyelarasan IT dan investasi portfolio IT yang berbeda.

Rintangan besar yang dihadapi dalam melakukan penyelarasan adalah karena perubahan yang selalu terjadi, baik perubahan dalam strategi bisnis maupun perubahan dalam teknologi. Handerson dalam menyebutkan tidak ada perusahaan yang dapat mencapai keselarasan karena bisnis dan teknologi yang selalu berubah. 


\section{KESIMPULAN DAN SARAN}

Dalam pembahasan di atas, bahwa strategi Teknologi Informasi harus sesuai dengan strategi bisnis dan dapat menggambarkan bagaimana merumuskan strategi Teknologi Informasi yang sesuai dengan bisnis strategi, sebagai bagian integral dari strategi bisnis, dapat memenuhi kebutuhan bisnis yang lebih baik, meningkatkan daya saing inti perusahaan dan mencapai tujuan strategis perusahaan. Dari apa yang telah dibahas di atas, jelas bahwa perencanaan strategis Teknologi Informasi berdasarkan strategi bisnis menentukan arsitektur Teknologi Informasi masa depan, masukan dan perbaikan berdasarkan strategi bisnis, struktur organisasi, operasi proses dan status aplikasi Teknologi Informasi hanya teknologi informasi ini cocok untuk layanan manajemen dan teknologi informasi melayani manajemen strategi perusahaan dan manajemen bisnis, maka informasi teknologi dapat meningkatkan kapasitas berkelanjutan pengembangan usaha dan meningkatkan inti daya saing perusahaan dan semua ini pada akhirnya membantu perusahaan mencapai strategi bisnis mereka.

\section{DAFTAR RUJUKAN}

Alonso, I.A.; Verdun, J.C.; Caro, E.T., "The Importance of IT Strategic Demand Management in Achieving the Objectives of the Strategic Business Planning," Computer Science and Software Engineering, 2008 International Conference on , vol.2, no., pp.235,238, 12-14 Dec. 2008 doi:10.1109/CSSE.2008.1307 URL: http://ieeexplore.ieee.org/stamp/stamp.jsp?tp=\&arnumber=4722042\&isnumber $=472$ 1981

Nogueira, A.R.R.; Reinhard, N., "Strategic IT management in Brazilian banks," System Sciences, 2000. Proceedings of the 33rd Annual Hawaii International Conference on , vol., no., pp.9 pp. vol.2, 4-7 Jan. 2000 doi: 10.1109/HICSS.2000.926916 URL: http://ieeexplore.ieee.org/stamp/stamp.jsp?tp=\&arnumber=926916\&isnumber=20043

Petruzzi, G.L.; Garavelli, A.C., "The strategic value of the "fit" between business processes and IT management: The case of the Italian publishing industry," Business- Driven IT Management, 2007. BDIM '07. 2nd IEEE/IFIP International Workshop on , vol., no., pp.110,111, 21-21 May 2007 doi: 10.1109/BDIM.2007.375021 URL: http://ieeexplore.ieee.org/stamp/stamp.jsp?tp=\&arnumber $=4261110 \&$ isnumber $=426108$ 9

Abdi, M.; Dominic, P. D D, "Strategic IT alignment with business strategy: Service oriented architecture approach," Information Technology (ITSim), 2010 International Symposium in , vol.3, no., pp.1473,1478, 15-17 June 2010 doi: 10.1109/ITSIM.2010.5561624 URL: http://ieeexplore.ieee.org/stamp/stamp.jsp?tp=\&arnumber=5561624\&isnumber=556145 2 